\title{
Durability Assessment of Gypsum Boards with Glass Mat Reinforcement Used in Light Facade Systems
}

\author{
Mauricio M. Resende ${ }^{1}$, Douglas C. Meirelles ${ }^{2}$, \\ Gustavo R. Boriolo ${ }^{3}$ and Luciana A. Oliveira ${ }^{4}$ \\ ${ }^{1}$ Institute of Technological Research of State of São Paulo - IPT, Building Technological Center - \\ CETAC, and São Judas University, mresende@ipt.br \\ ${ }^{2}$ Saint-Gobain Brasil, douglas.meirelles@saint-gobain.com \\ ${ }^{3}$ Saint-Gobain Research Brasil, gustavo.boriolo@saint-gobain.com \\ ${ }^{4}$ Institute of Technological Research of State of São Paulo - IPT, Building Technological Center - \\ CETAC, luciana@ipt.br
}

\begin{abstract}
Gypsum boards with glass mat reinforcement are used in light weight facade systems. These boards were recently brought to the Brazilian market. Therefore, there are few studies and little practical knowledge of their performance over time, mainly concerning to durability. The gypsum boards manufacturers set that these boards always need to be coated, however they can be exposed to natural conditions during the construction site period. A study is necessary to evaluate the feasibility of using these boards in Brazil, since the exposure conditions relating to humidity, temperature and solar radiation are different from Europe and North America. The aim of this paper is to show the approach used to evaluate the durability of the gypsum board with glass mat reinforcement, and also show the test results. In order to establish the durability approach, standards were adopted, as well as the functional performance concept. In addition, the tests considered that such boards would be used on the facade and should behave similarly to other boards used in facades in Brazil, such as fiber cement boards. Thus, mechanical tests were done in steady state, saturated and after aging in cycles of immersion, drying and heating. Other evaluations were made on gypsum boards applied on exposed walls. The results showed that even the board strength decreases after the accelerated aging cycles, the final value remains in an acceptable level. In addition, boards applied on exposed walls for 12 months have been presenting a good performance; meaning no cracks neither detachments, even though the follow-up still needs to be maintained longer.
\end{abstract}

Keywords: Gypsum Boards with Glass Mat Reinforcement, Durability, Performance, Aging.

\section{Introduction}

Gypsum boards with glass mat reinforcement ${ }^{1}$ were recently brought to the Brazilian market and it has been used in light weight facade systems ${ }^{2}$. There are no Brazilian standards concerning these boards, however, there are American and also European standards (ASTM C1177, 2017 and EN 15283-1, 2009) and some publications relating to moisture resistance

\footnotetext{
${ }^{1}$ Gypsum boards with mat reinforcement are composed of set gypsum plaster core reinforced with inorganic fibers which are arranged in a woven or non-woven mat to form flat rectangular boards. Admixtures, fillers and fibers dispersed in the core may also be present (definition of EN 15283-1,2009).

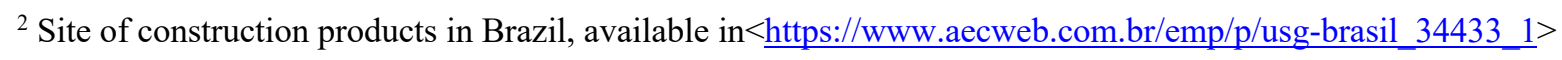


(CMHC, 2007; Randall et al., 2016). Although, these standards and publications, there are few studies and little practical knowledge of the performance of these boards over time in Brazil, mainly concerning to durability requirements. Singh and Garg (1992) have defined the durability of glass reinforced gypsum composite by assessing its behavior in water, in natural weathering exposition and after wetting and drying aging cycles.

The use of glass mat gypsum boards in external facades is recommended only as a substrate to a coating system - whether a Direct Applied Finish System (DAFS) or an External Insulated Finish System (EIFS). Glass mat board manufacturers set that these boards cannot stay apparent, meaning no coating, during their entire service life. However, they may be exposed to natural conditions during the construction site period during one year atmost.

The boards are used as a component of a facade system. Once assembled in facades, they must contribute to ensure the design life (DL) of the complete system. This is an actual discussion in Brazil, mostly because of the residential building performance standard, ABNT NBR 15.575-1 (2013), set a minimum DL of 40 years for façade systems of residential buildings.

A study is necessary to evaluate the feasibility of using these boards in Brazil, because of the design life requirement set on NBR 15575 and because of the exposure conditions relating to relative humidity, temperature and solar radiation are different among Europe, North America and Brazil. For example the average temperature in South East Brazil is around $23^{\circ} \mathrm{C}$ and $76 \%$ of relative humidity, with an average solar radiation of $18 \mathrm{MJ} /(\mathrm{m} 2$.dia) (Tiba, 2000, Inmet site - available in < http://www inmet.gov.br/portal/>.

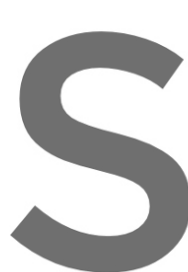
In this context, the durability of the gypsun building in Brazil, and durability assessment of system.
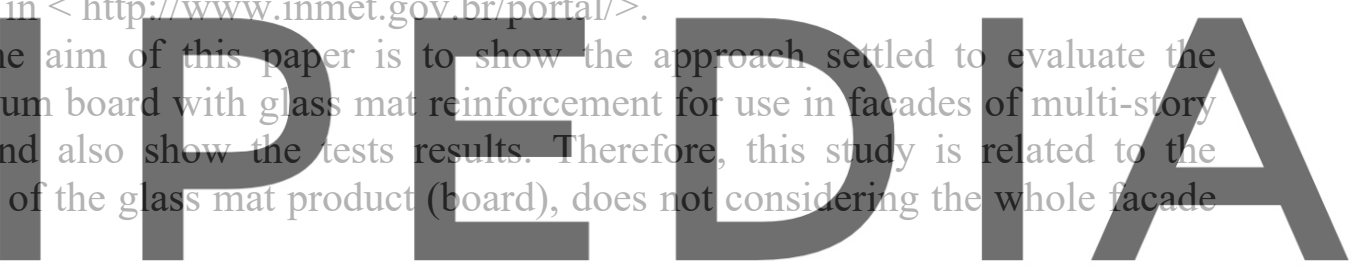

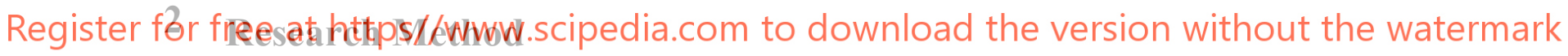

The durability approach settled here is according to ISO 15686-2 (2012) concepts: a) definition of user needs, material requirements and characterization; b) preparation identifications of aging agents, mechanisms and effects, choice of performance characteristics and evaluation techniques; c) exposure and evaluation - short-term exposure (accelerated exposure) and long-term exposure (field exposure); and analyzing and interpretation. The table 1 shows the durability approach developed to this study based on the authors experience and knowledge. 
Mauricio M. Resende, Douglas C. Meirelles, Gustavo R. Boriolo and Luciana A. Oliveira

Table 1. Durability approach developed to this study, based on ISO 15686-2 (2001) concepts.

\begin{tabular}{|c|c|c|}
\hline Stage & Descriptions/ Definitions & Reference \\
\hline Definitions & $\begin{array}{c}\text { The intention is to use this gypsum } \\
\text { board in facades of multi-story } \\
\text { building in Brazil façades in Brazil }\end{array}$ & Principles set to this work \\
\hline User needs & $\begin{array}{c}\text { Strength reversability } \\
\text { Moisture resistance }\end{array}$ & $\begin{array}{c}\text { CMHC (2007); Randall et al. } \\
\text { (2016) and Singh and Garg } \\
\text { (1992) }\end{array}$ \\
\hline $\begin{array}{c}\text { Performance requirements } \\
\text { relating to gypsum board } \\
\text { durability }\end{array}$ & \begin{tabular}{c} 
(19) \\
\hline
\end{tabular}
\end{tabular}

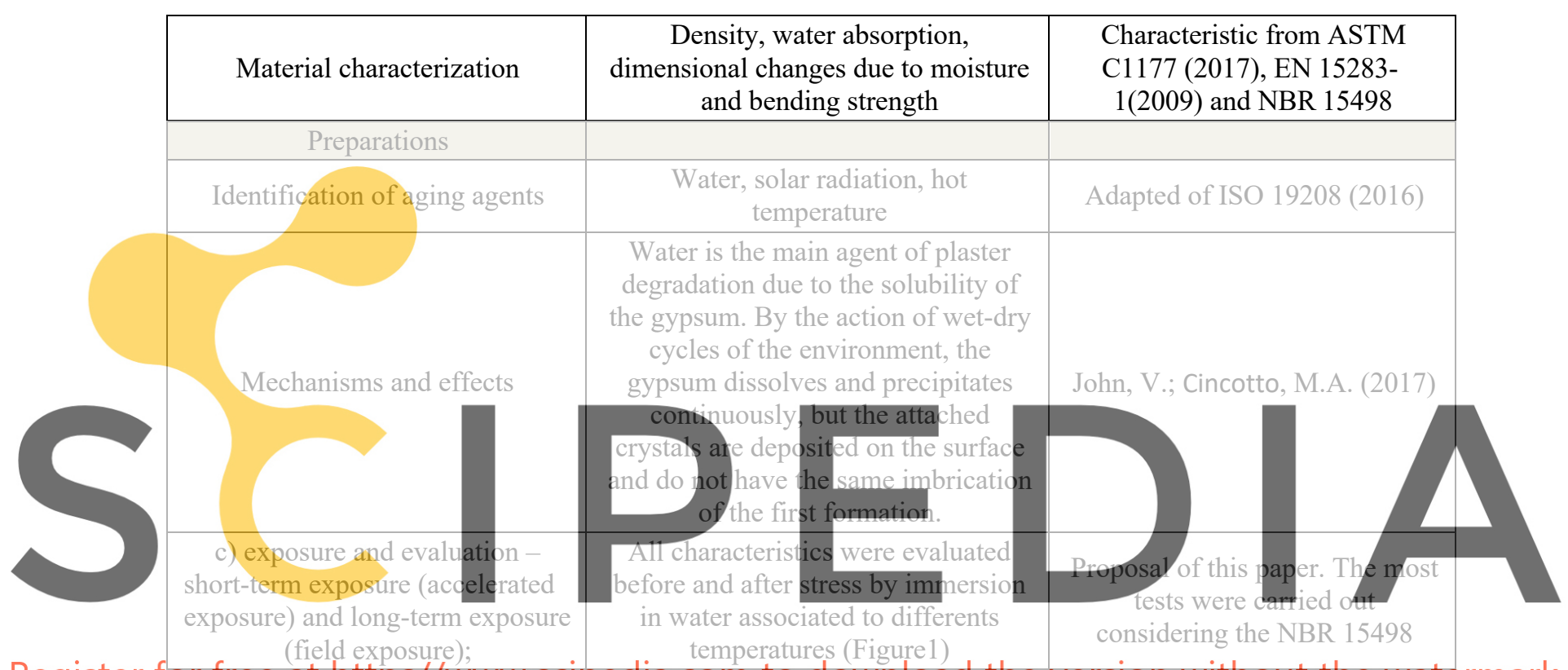

\section{Register for free at https//www.scipedia.com to download the version without the watermark}

The tests (characteristics evaluation before and after short term exposure) were designed

considering that gypsum boards with glass mat reinforcement will be used on the facade and should behave similarly to other boards applied in facades in Brazil, such as fiber cement boards, even they will be coated after at maximum one year (Figure 1). Then, mechanical tests were done in steady state, saturated and after aging (cycles of immersion in water and drying), since the water is the most important aging agent for these boards (Figure 1).

In additional, a field exposure is carrying on since four gypsum boards were assembled on exposed walls it has been twelve months. These walls are in São Paulo city, West region, placed directed to North. 
Mauricio M. Resende, Douglas C. Meirelles, Gustavo R. Boriolo and Luciana A. Oliveira

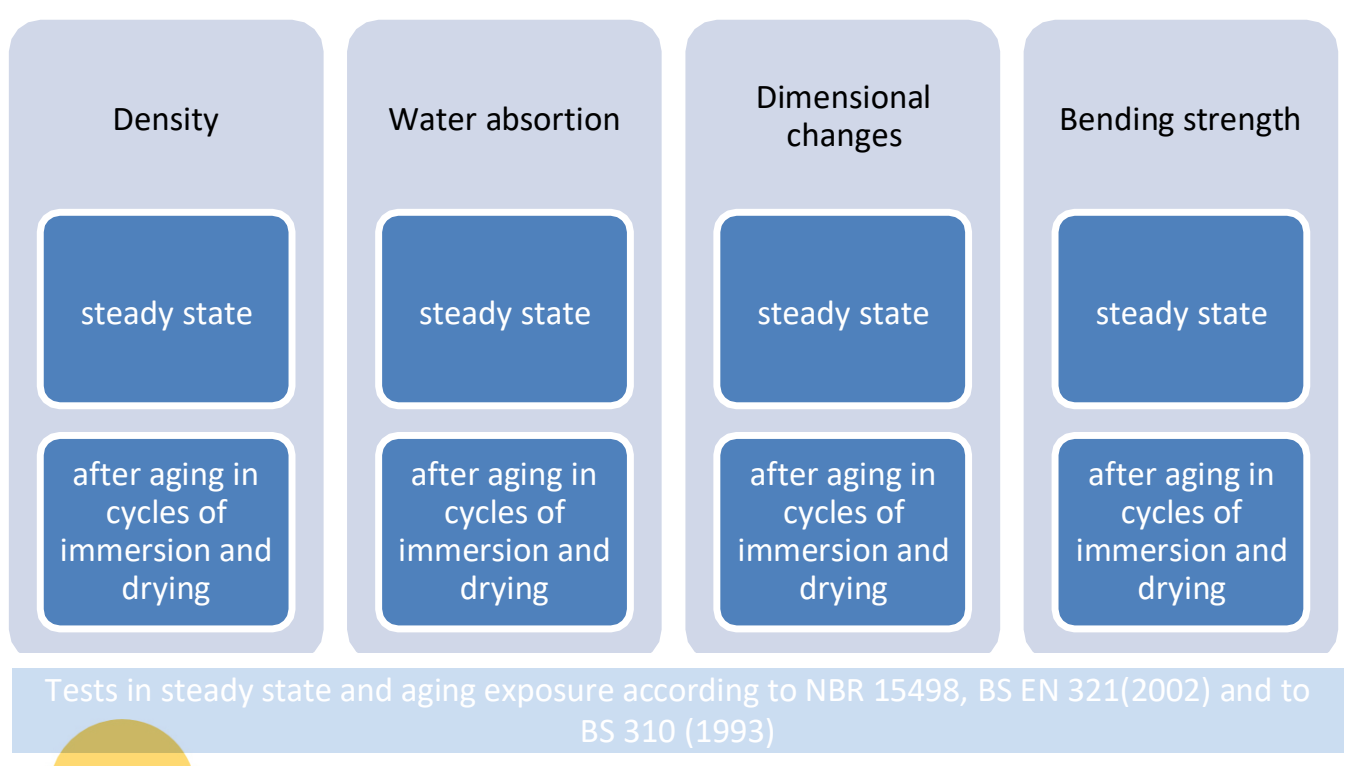

Figure 1. Tests of gypsum boards under stress condition.

The test in normal condition, steady state, means keeping the samples for three days to $(20 \pm 2)^{\circ} \mathrm{C}$ and $(50 \pm 5) \%$ of relative humidity. Two kinds of short aging exposure were carried on: one adopting the fiber cement standard (ABNT NBR 15498, 2016) and the other adopting the OSB board standard (BS EN 321, 2001).

The aging test specifie

50 aging cycles. Each cyc

hours and exposure

consists of subjecting
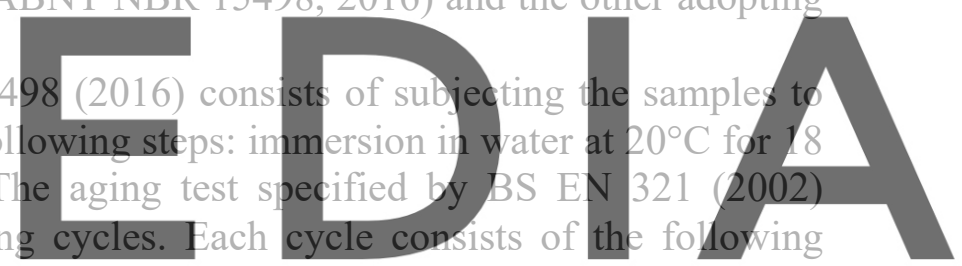

steps: immersion in water at $20^{\circ} \mathrm{C}$ for 72 hours, then exposure at $-12^{\circ} \mathrm{C}$ for 24 hours and

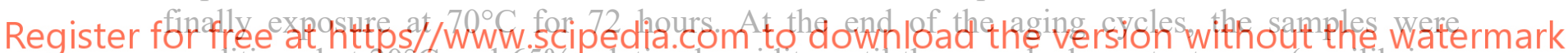
conditioned at $20^{\circ} \mathrm{C}$ and $65 \%$ relative humidity until they reached constant mass (equilibrium condition). In the state condition, it determined the flexural tensile strength and the modulus of elasticity of aged and non-aged samples according to BS EN 310 (1993).

\section{Results and Discussion}

\subsection{Density}

According to NBR 15498 (2016) samples of gypsum boards were measured and weighed; the average results can be seen in Table .

Table 2. Gypsum boards with glass mat reinforcement densities.

\begin{tabular}{ccc}
\hline Steady state & $\begin{array}{c}\text { After aging in cycles } \\
\text { of immersion and } \\
\text { drying }{ }^{(1)}\end{array}$ & $\begin{array}{c}\text { Difference between } \\
\text { normal and aging } \\
\text { conditions }\end{array}$ \\
\hline $798,6 \pm 6,30 \mathrm{~g}$ & $784,13 \pm 19,45 \mathrm{~g}$ & $14,47 \mathrm{~g}(1,81 \%)$ \\
\hline${ }^{(1)}$ aging exposure according to NBR 15498 & \\
\hline
\end{tabular}




\subsection{Water Absorption}

Moisture content was calculated, according to NBR 15498, using 250x100 mm samples for gypsum board, which are the same sizes of the bending test samples. The results shown in Table 3 are the average of 10 samples at $21^{\circ} \mathrm{C}$ and $65 \% \mathrm{RH}$.

Table 3. Moisture content of Gypsum boards with glass mat reinforcement (average result).

\begin{tabular}{lcc}
\hline Steady state & $\begin{array}{c}\text { After aging in cycles } \\
\text { of immersion and } \\
\text { drying }{ }^{(1)}\end{array}$ & $\begin{array}{c}\text { Difference between } \\
\text { normal and aging } \\
\text { conditions }\end{array}$ \\
\hline$(36,6 \pm 0,95) \%$ & $(55,5 \pm 3,4) \%$ & $18,9 \%$ \\
\hline (1) aging exposure according to NBR 15498 \\
\hline
\end{tabular}

In additional, the moisture content tested according to EN 15283-1 (standard for Gypsum boards with fibrous reinforcement), is around 4\%, which means these boards is Type H1, with reduced water absorption rate.

33

Dimensional Changes

The dimensional changes relating to width and length were tested using 250x100 mm samples \begin{tabular}{l} 
for gypsum board, which are the same sizes of the bending test samples. The results shown in \\
Table are the average of 10 samples. \\
Table 4. Dimensional change in wilth and length. \\
\hline
\end{tabular}

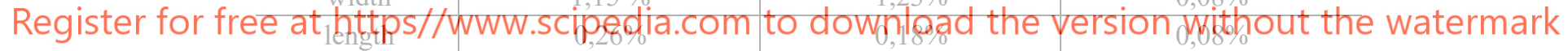
aging exposure according to NBR 15498

\subsection{Bending Strength after Immersion and Dry}

The bending strength according to NBR 15498 (2016) was tested using 250x100 mm samples for gypsum board. The results shown in Table 5 are the average of 10 samples.

\section{Bending Strength and Modulus after Immersion, Freezing and Heating}

The bending strength and modulus of gypsum board was tested using $250 \mathrm{mmx} 50 \mathrm{~mm}$ according to BS EN 310 (1993), in steady conditions and after short aging exposure, that was based on BS EN 321 (wood board) as showed in Table 6. 
Table 5. Bending strength results before and after short term exposure.

\begin{tabular}{c|c|c|c|c}
\hline Requirements & Steady state & $\begin{array}{c}\text { Saturated } \\
\text { condition - } \\
\text { immersion in } \\
\text { water for 24hours }\end{array}$ & $\begin{array}{c}\text { Steady state, after } \\
\text { aging in cycles of } \\
\text { immersion and } \\
\text { drying** }\end{array}$ & $\begin{array}{c}\text { Satured condition, } \\
\text { after aging in cycles of } \\
\text { immersion and drying }\end{array}$ \\
\hline $\begin{array}{c}\text { Bending strength } \\
\text { Longitudinal direction } \\
(\mathrm{MPa}) *\end{array}$ & $7,9 \pm 0,5$ & $4,7 \pm 0,4$ & $5,9 \pm 0,2$ & $2,6 \pm 0,2$ \\
\hline $\begin{array}{c}\text { Bending strength } \\
\text { Transversal direction } \\
(\mathrm{MPa}) *\end{array}$ & $6,0 \pm 0,8$ & $4,3 \pm 0,5$ & $4,5 \pm 0,6$ & $2,2 \pm 0,2$ \\
\hline
\end{tabular}

* the samples were removed from the gypsum board considering longitudinal and transversal direction

$* *$ at the end of the aging cycles, the samples were conditioned at $20^{\circ} \mathrm{C}$ and $65 \%$ relative humidity until they reached constant mass (equilibrium condition).

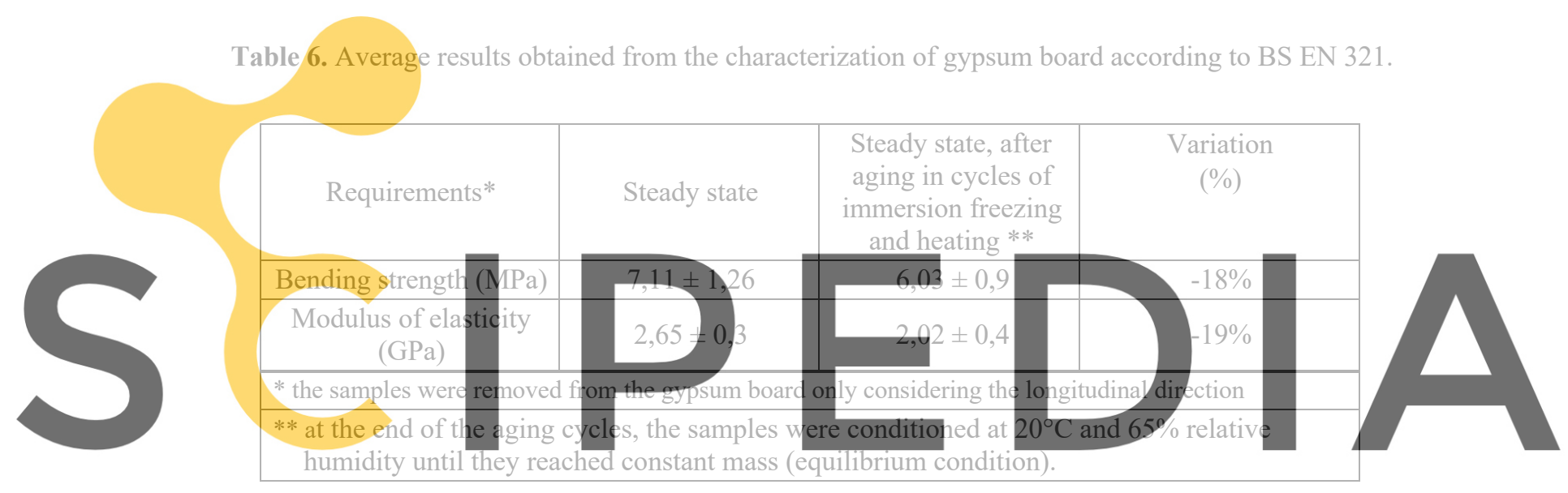

\section{Register for free at. attps/bwww. scipedia,com, to downloand the version without the watermark reinforcement in steady state and after aging exposure were under 20\%; density was almost} zero, water absorption was around $18 \%$ and dimensional changes were around $0,08 \%$. Relating to bending strength, the results in the saturated state were greater than $50 \%$ of the results in the steady state. The ratio of bending strength in the transversal by the longitudinal direction was greater than $70 \%$, both in the steady and saturated state. These bending strength results meet the NBR 15498 specifications. Once considering a severe condition, the bending strength in saturated state after aging was $50 \%$ of the bending strength of the saturated boards in steady state. Relating to the exposure to wetting / freezing / heating cycles by BS EN 321, it can be seen from the analysis of Table 4 that both the bending strength and the modulus of elasticity after the aging cycles presented values above $80 \%$ of the initial values. 


\subsection{Long-Term Exposure (Field Exposure)}

Gypsum boards mat reinforcement were installed in two walls structured by steel frame, forming a wall of $2400 \mathrm{~mm}$ wide x $2400 \mathrm{~mm}$ length. After 12 months of exposure, no significant occurrences (no cracks neither detachments or wraps) were found on the boards.

\section{Conclusions}

This paper shows an approach to evaluate the durability of gypsum boards mat reinforcement used in the facade, considering water as the main aging agent, since the board may have contact with rainwater and solubilize the plaster. Then, tests were made to evaluate the physical and mechanical characteristics of these boards under normal condition (steady state) and after aging, cycles of immersion in water and drying. It was assumed that glass mat gypsum boards should behave similarly to other facade sheets, such as fiber cement and wood boards. For this reason, it was adopted the aging exposure methods indicated in both standards.

Concluding, the tests results show that the difference between physical characteristics before and after aging is less than 20\%. Regarding to the mechanical characteristics, the bending strength losses after aging were on average less than $50 \%$. However, after conditioning under normal conditions there is a resistance return, the strength after aging, at

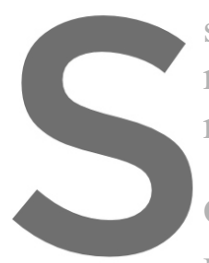
steady state, is simila natural exposure, the boa needs to be maintained

ORCID
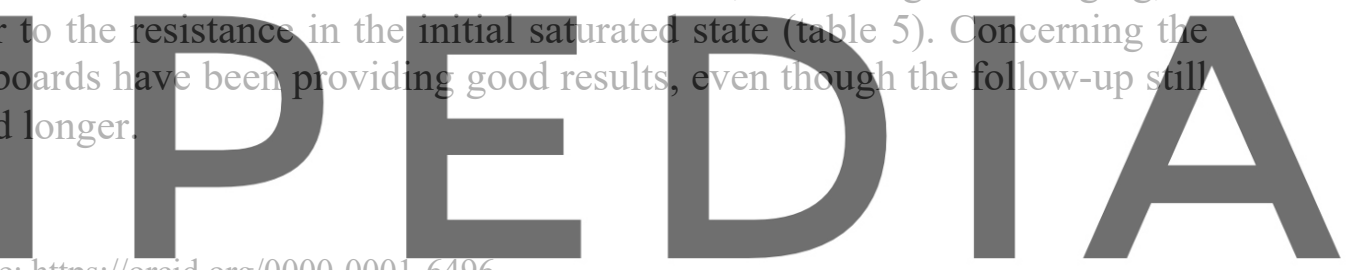

Maurício Marques Resende: https://orcid.org/0000-0001-64 0762 Douglas Meirelles: https://orcid.org/0000-0001-5203-

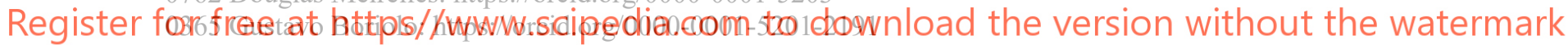
Luciana Oliveira: http://orcid.org/0000-0001-6772-3252 


\section{References}

ABNT. (2016). NBR 15498 (Placa de fibrocimento sem amianto - Requisitos e métodos de ensaos). Associação Brasileira de Normas Técncias, Brasil.

ABNT. (2013). NBR 15575-1 (Edificações Haitacionais - Desempenho - Parte 1: Requisitos Gerais). Associação Brasileira de Normas Técncias, Brasil.

ABNT. (2013). NBR 15575-4 (Edificações Haitacionais - Desempenho - Parte 4:Requisitos para os sistemas de vedações verticais internas e externas - SVVIE). Associação Brasileira de Normas Técncias, Brasil.

ASTM. (2017). ASTM C1177 (Standard Specification for Glass Mat Gypsum Substrate for Use as Sheating). American Standard Tecnhical Materials, USA.

BSI. (1993a). BS EN 310 (Wood-based panels - Determination of modulus of elasticity in bending and of bending strength). British Standards Institution, UK.

BSI. (2002b). BS EN 321 (Wood-based panels - Determination of moisture resistance under cyclic test conditions). British Standards Institution, UK.

Canada Mortgage and Housing Corporation - CMHC (2007). Technical Series 07-100. Relationship Between Moisture Content and Mechanical Properties of Gypsum Sheathing. Montreal.

CEN. (2009). BS EN 15283-1 (Gypsum boardas with fibrous reinforcement-Definitions, requirements and test methods - Part 1: Gypsum boards with mat reiforcement). Comité Européen de Normalisation, UK.

ISO. (2016). ISO 15686-2 (Buildings and constructer assets - Service life planning - Part 2: Service lefe prediction procedures). International Standard Organization.

ISO. (2016). ISO 19208 ( Framework for specifying performance in buildings). International Standard Organization.

John, V. and Cincotto, M.A. (2017). Gesso para construção Civil. In: Isaia, G. Materiais de Construção Civil e princípios de ciência e engenharia dos materiais. $3^{a}$ edição. São Paulo: Ibracon, Capítulo 23. ISBN: 978-8598576-27-5.

Randall, B.G., Barber,W Exterior Insulation an (EIFS): Performance, 10.1520/STP158520140110.

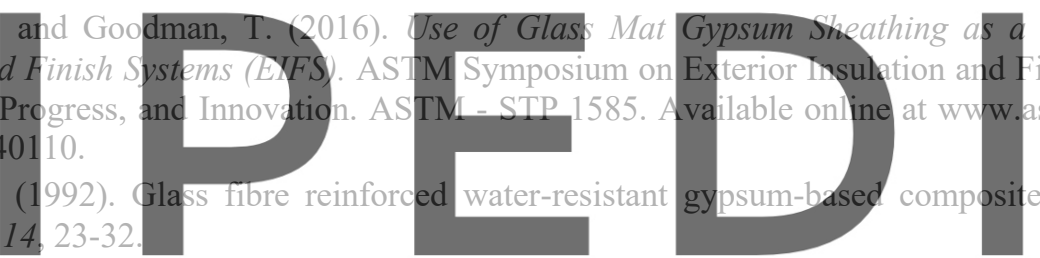

Concrete Composites, 14. 23-32

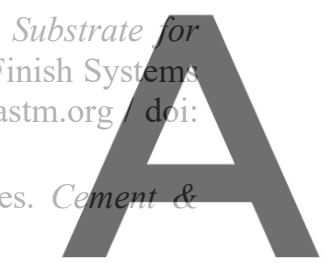

Tiba, C. et. al. (2000). Atlas Solarimétrico do Brasil : banco de dados solarimétricos / coordenador Recife : Ed. 